\title{
The internal morphology of primary spines of extant regular echinoids in the tropical western Atlantic: a SEM atlas
}

\author{
Stephen K. Donovan ${ }^{1}$
}

Received: 19 March 2018/Accepted: 5 July 2018/Published online: 1 August 2018

(C) Akademie der Naturwissenschaften Schweiz (SCNAT) 2018

\begin{abstract}
The spines of echinoids are common palaeontological objects, but rarely supply more than this minimal information, because they are difficult to identify to genus or species. Some taxa, particularly cidaroids, may be named based on the external morphology of their spines, but this is of no assistance when identifying spines in thin section. Yet, the internal complexities of the stereom of the echinoid spine may be unique to a particular species or, at least, genus or family. A scanning electron micrograph (SEM) atlas of the internal structure of the primary spines of 14 of the most common species of regular echinoids from shallow-water environments of the tropical western Atlantic Ocean is presented herein. This demonstrates the stereom structure of the spines of each of these species by reference to multiple images. Plates of SEMs are supplemented by brief descriptions and comparisons. This atlas is intended as a tool that can be applied to diverse aspects of palaeontological and sedimentological studies in thin section.
\end{abstract}

Keywords Palaeoecology $\cdot$ Pliocene $\cdot$ Pleistocene $\cdot$ Preservation $\cdot$ Completeness of the fossil record

\section{Introduction}

The Palaeontological Association Newsletter publishes a regular series of images of 'mystery fossils' that have previously defied the best attempts of researchers to identify them; the readership are invited to do better. The only mystery fossil to attract a reply from me, which was several years ago, was a thin section through a Neogene (Pleistocene?), shallow-water limestone which had sliced through a primary spine of a diadematoid echinoid. I sent my identification to the 'mystery fossils' editor and was, by reply, informed that I was wrong and that the specimen had already been identified as a holothurian ossicle. I knew that this was erroneous, yet despite my qualifications to identify an echinoid spine in thin section, the editor of 'mystery fossils' was adamant-it was holothurian, not echinoid. I then suggested that a leading expert on extant echinoids

Editorial Handling: D. Marty.

Stephen K. Donovan

Steve.Donovan@naturalis.nl

1 Taxonomy and Systematics Group, Naturalis Biodiversity Center, Postbus 9517, 2300 RA Leiden, The Netherlands and holothurians might be approached as a neutral referee; he agreed that it was an echinoid.

This story demonstrates that even an experienced geologist can have trouble identifying a section through one of the commonest of fossil echinoderm fragments in thin section, that is, an echinoid spine. The present contribution aims to help correct this aberration, at least in part, by providing an atlas of some of the commoner echinoid spines that might be found in shallow-water limestones in the region that I know best, that is, in the tropical western Atlantic. This will enable identification to a high taxonomic level and even to species in some distinctive examples. Although the examples are Recent, many of these taxa are already known from the Neogene of the region (Donovan 2001, 2003) and, with the aid of this atlas, others may soon be added to the list. Furthermore, many of the genera considered have a broad distribution in the tropics and may have a wider geographic applicability.

The collections of the Department of Invertebrate Zoology, National Museum of Natural History (USNM), which were used in the present study, include abundant specimens of all but a few relevant species (Table 1). The data produced by this project are relevant to ongoing debates regarding the completeness and adequacy of the fossil record (Donovan and Paul 1998; see "Discussion" 
Table 1 Shallow-water regular echinoids of the tropical western Atlantic considered herein (culled from Serafy 1979, Table 2; Hendler et al. 1995)

\begin{tabular}{ll}
\hline Species & Depth range (m) \\
\hline Order Cidaroida & $0-800$ \\
Eucidaris tribuloides (De Lamarck, 1816) & $23-1000$ \\
Stylocidaris affinis (Philippi, 1845) & $48-625$ \\
Tretocidaris bartletti (A. Agassiz, 1880) & \\
Order Echinothuroida & $50-3700$ \\
Phormosoma placenta Wyville Thomson, 1872 & \\
Order Diadematoida & $0-400$ \\
Diadema antillarum (Philippi, 1845) & $11-88$ \\
Astropyga magnifica A. H. Clark, 1934 & $33-310$ \\
Centrostephanus longispinus (Philippi, 1845) & \\
Order Arbacioida & $0-225$ \\
Arbacia punctulata (De Lamarck, 1816) & \\
Order Temnopleuroida & $12-420$ \\
Genocidaris maculata A. Agassiz, 1869 & $0-250$ \\
Lytechinus variegatus (De Lamarck, 1816) & $5-92$ \\
Lytechinus williamsi Chesher, 1968 & $0-55$ \\
Tripneustes ventricosus (De Lamarck, 1816) & \\
Order Echinoida & $0-45$ \\
Echinometra lucunter (Linné, 1758) & $0-40$ \\
Echinometra viridis A. Agassiz, 1863 & \\
\hline
\end{tabular}

For this study, shallow water is considered to be between 0 and $50 \mathrm{~m}$ water depth. All are well-represented in the collections of the Department of Invertebrate Zoology, USNM

below). Although Benton and Simms (1995, 1996) have favourably compared the quality of the vertebrate and echinoderm fossil records, part of the poor quality of the latter is due to the generally limited ability of palaeontologists to accurately identify the disarticulated skeletal elements of echinoderms (Donovan 1996). While many authors have been diligent in their efforts to provide a solid basis for the identification of disarticulated echinoderm ossicles, notably including Hans Hess, remembered in this present volume, one has only to pick up a fist-sized class of fossiliferous Mississippian limestone to see dozens of ossicles that remain indeterminate apart from an appellation as broad as, say, 'crinoid'. These and other echinodermal elements are present in rocks throughout the Phanerozoic, are often of distinct morphology, may be present in such quantities that they are a major rockforming component (Ausich 1997), and yet are largely ignored by systematists. The aim of the present study is to inform part of this ignorance.

The terminology of the echinoid endoskeleton used herein follows Melville and Durham (1966), Durham and Wagner (1966), Smith (1984) and Smith and Kroh (2011).
Specimens discussed and figured below are in the collections of the Department of Invertebrate Zoology, National Museum of Natural History, Smithsonian Institution, Washington, D.C. (USNM).

\section{Materials and methods}

With only the few exceptions listed in Table 2, all regular echinoids from shallow-water environments of the tropical western Atlantic are discussed below. These taxa are wellrepresented in the collections of the Department of Invertebrate Zoology, USNM (Table 1). All of these species include at least some specimens that have shed some of their primary and larger secondary spines. Representative spines for each species in Table 1 were selected. Rather than remove primary spines afresh from specimens, those that had dropped from tests were preferred; many of these were already broken. A registration number may refer to one or multiple echinoids; loose spines could not be related back to their original tests with confidence.

These spines were cleaned for 3-4 $\mathrm{h}$ in a dilute solution of 'Clorox' bleach, thoroughly washed in tap water, dried by blotting and left in a gentle heat overnight. Representative fragments were broken from the spines of each species and mounted for SE microscopy on aluminium stubs using double-sided adhesive tape. Up to three SEM stubs were made up for each species, each stub bearing $2-4$ spine fragments. These stubs were coated with $60 \%$ goldpalladium and photographed using a Hitachi TM3000 Tabletop SEM facility of the USNM. Images have been manipulated using Adobe Photoshop and arranged as plates of SE micrographs (Figs. 1, 2, 3, 4, 5, 6, 7, 8, 9, 10, 11, 12, 13, 14). Detailed descriptions of spine morphology are already available, particularly in Mortensen (1928-1951),

Table 2 Shallow-water regular echinoids of the tropical western Atlantic not considered herein (culled from Serafy 1979, Table 2; Pawson et al. 2009)

\begin{tabular}{ll}
\hline Species & Depth range (m) \\
\hline Order Cidaroida & $13-800$ \\
Cidaris abyssicola (A. Agassiz, 1869) & $46-790$ \\
Cidaris rugosa (H. L. Clark, 1907) & $0-800$ \\
Steroeocidaris ingolfiana Mortensen, 1903 & \\
Order Temnopleuroida & $22-350$ \\
Lytechinus callipeplus H. L. Clark, 1912 & $12-155$ \\
Pseudoboletia maculata Troschel, 1869 &
\end{tabular}

For this study, shallow water is considered to be between 0 and $50 \mathrm{~m}$ water depth 
Fig. 1 Eucidaris tribuloides (Lamarck), USNM 10734, SE micrographs of broken sections through primary spines. a Stub A1, b Stub A3, c Stub A2, d Stub A1 (this is a different specimen from a, but on the same stub). All scale bars represent $1 \mathrm{~mm}$

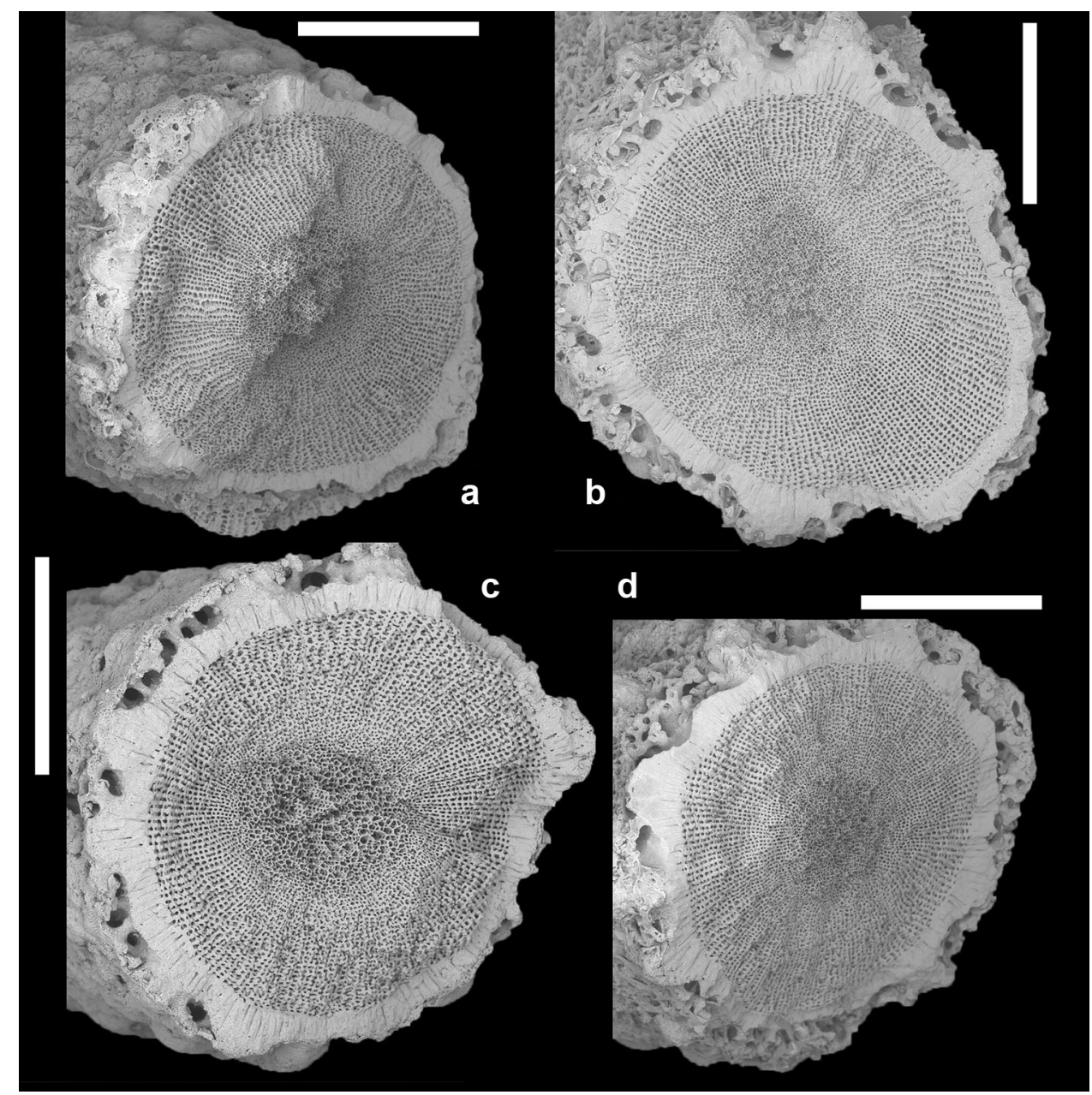

but also see below. Stubs are housed in the USNM in the same drawers as the echinoids from which spine fragments were removed. Relevant information is provided such as available ecological data (both published, and derived from specimens and their labels), such as depth distribution (Table 1; "Appendix").

\section{Notes on spines}

Informative discussions of the internal structure of the spines of echinoids include Melville and Durham (1966, pp. U247-U249) and Smith and Kroh (2011).

Eucidaris tribuloides (Lamarck) (Fig. 1). Probably the best known fossil, yet still extant echinoid in the Antillean region, which is easily identified in hand specimen by its large and distinctive primary spines (Mortensen 1928, pp. 403-404; Cutress 1980; Donovan 1993, fig. 5). The internal structure of E. tribuloides has an irregular meshwork in the central medulla (= core), radial lamellae, and a dense cortex with radial pores (Gordon 1990). Spinules rounded in section (Fig. 1).

Stylocidaris affinis (Philippi) and Tretocidaris bartletti (A. Agassiz) (Figs. 2, 3, respectively). The spines of these species are similar, with an irregular meshwork in the central medulla, radial lamellae, and a dense cortex with radial pores (Figs. 2, 3). They differ from E. tribuloides (Fig. 1) in having sections through spinules of triangular, not rounded, section at the outer surface of the cortex (see also Mortensen 1928, pp. 316, 338).

Phormosoma placenta Wyville Thomson (Fig. 4). Hollow spines with a particularly broad lumen and a thin cortex of lamellar layer of one or two layers of wedge- 
Fig. 2 Stylocidaris affinis (Philippi), USNM 27840, SE micrographs of broken sections through primary spines. a Stub A4, b Stub A4 (different specimen from a). c Stub A5. d Stub A6. Scale bars a, b represent $500 \mu \mathrm{m}$, c, d represent $1 \mathrm{~mm}$

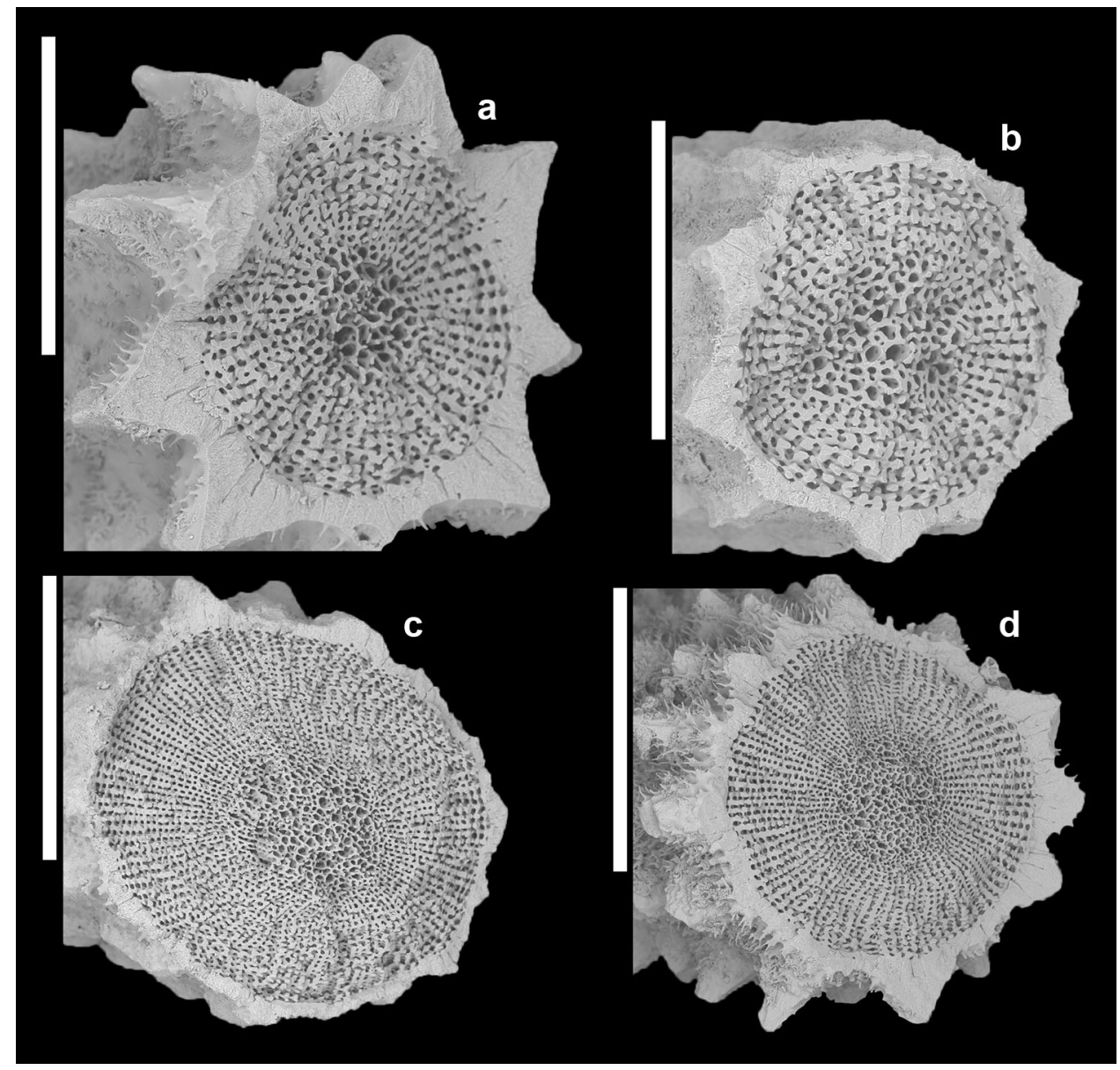

shaped ribs that present a smooth external surface (see also Mortensen 1935, p. 127).

Diadema antillarum (Philippi) and Centrostephanus longispinus (Philippi) (Figs. 5, 7, respectively). Diadematoids, so common as individuals in the modern Caribbean sea, had no known fossil record in the Antillean region until the seminal work of Gordon (1990) and Gordon and Donovan (1992) demonstrated that the disarticulated ossicles, particularly fragments of spines, could be exceedingly common locally. The transverse sections of $D$. antillarum and $C$. longispinus have similar transverse sections: a moderately broad, central lumen, except near the tip (Fig. 5c), where it is occluded by a narrow medulla; a thin, porous layer of sterom lining the lumen (= core?), and a broad lamella + cortex comprised of inverted triangular, wedge-like plates, close packed at the circumference, and linked internally by thin, concentric trabeculae (see also Mortensen 1940, pp. 272-273, 304, figs. 144b, 156a).
Astropyga magnifica A. H. Clark (Fig. 6). In section, the primary spines of A. magnifica differ from those of other shallow-water diadematoids from the region in commonly having a medulla of irregular stereom and more numerous 'layers' of concentric trabeculae supporting the inverted wedge-shaped plates of the cortex (Mortensen 1940, p. 206).

Arbacia punctulata (Lamarck) (Fig. 8). Somewhat similar to A. magnifica, but with the inverted wedge-shaped plates of the lamella and cortex layers separated by a more dense, irregular infill of stereom.

Genocidaris maculata A. Agassiz (Fig. 9). Distinctive spines with a narrow, central lumen, and the radial core/cortex comprised of only a few (commonly 6-8) broad, triangular wedges, linked by only one circlet of concentric trabeculae (Mortensen 1943 [Camarodonta I], p. 361, fig. 220). 
Fig. 3 Tretocidaris bartletti (A. Agassiz), USNM E11897, SE micrographs of broken sections through primary spines. a Stub A8. b Stub A8 (different specimen from a). c, d Stub A9, both ends of broken spine. All scale bars represent $1 \mathrm{~mm}$
Fig. 4 Phormosoma placenta sigsbei A. Agassiz, USNM E12320, SE micrographs of broken sections through primary spines. a Stub A10. b, c Stub A11, both ends of broken spine. d Stub A11 (different specimen from $\mathbf{b}, \mathbf{c}$ ). Scale bars a, d represent $500 \mu \mathrm{m}, \mathbf{b}$, c represent $200 \mu \mathrm{m}$
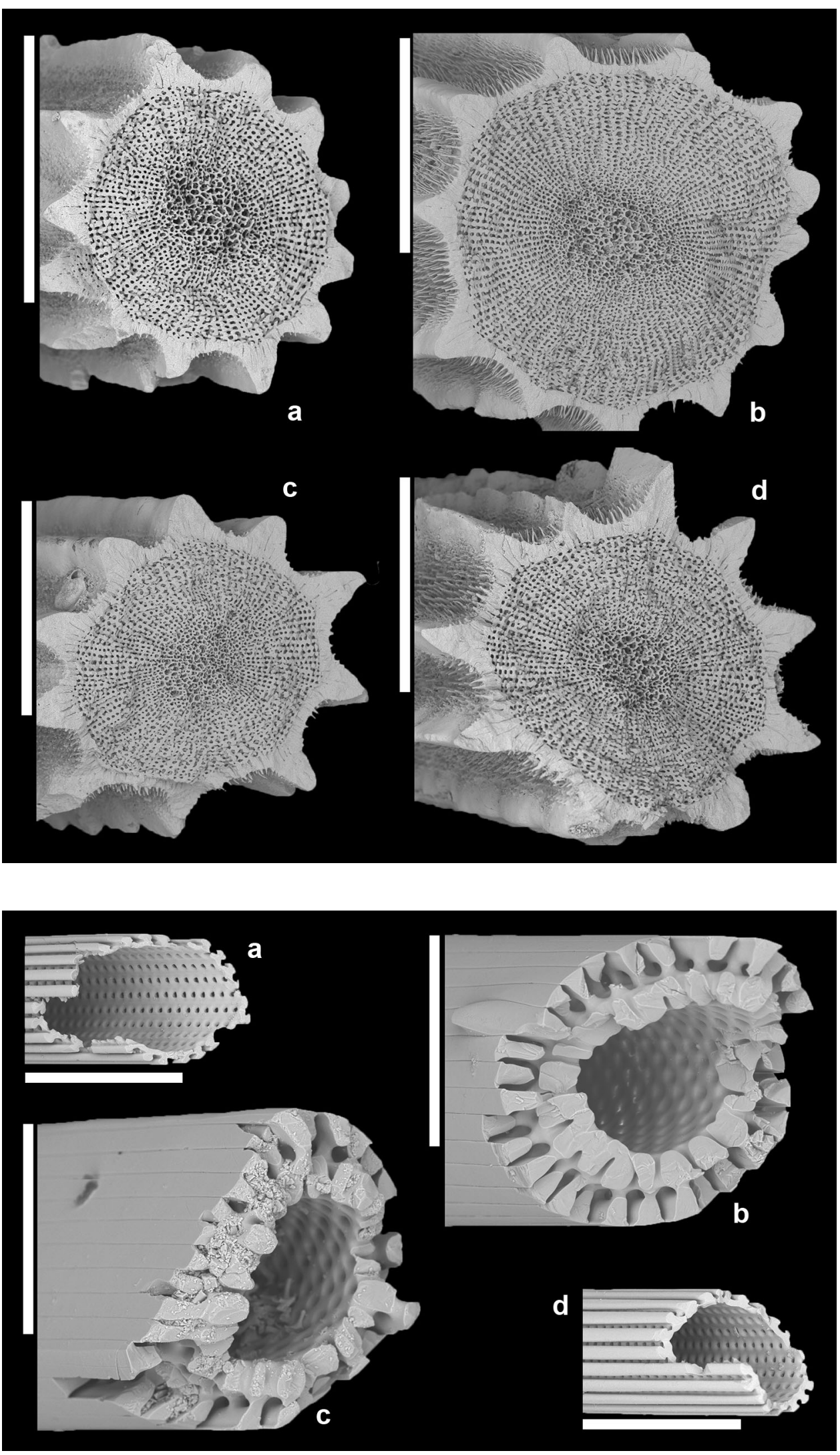


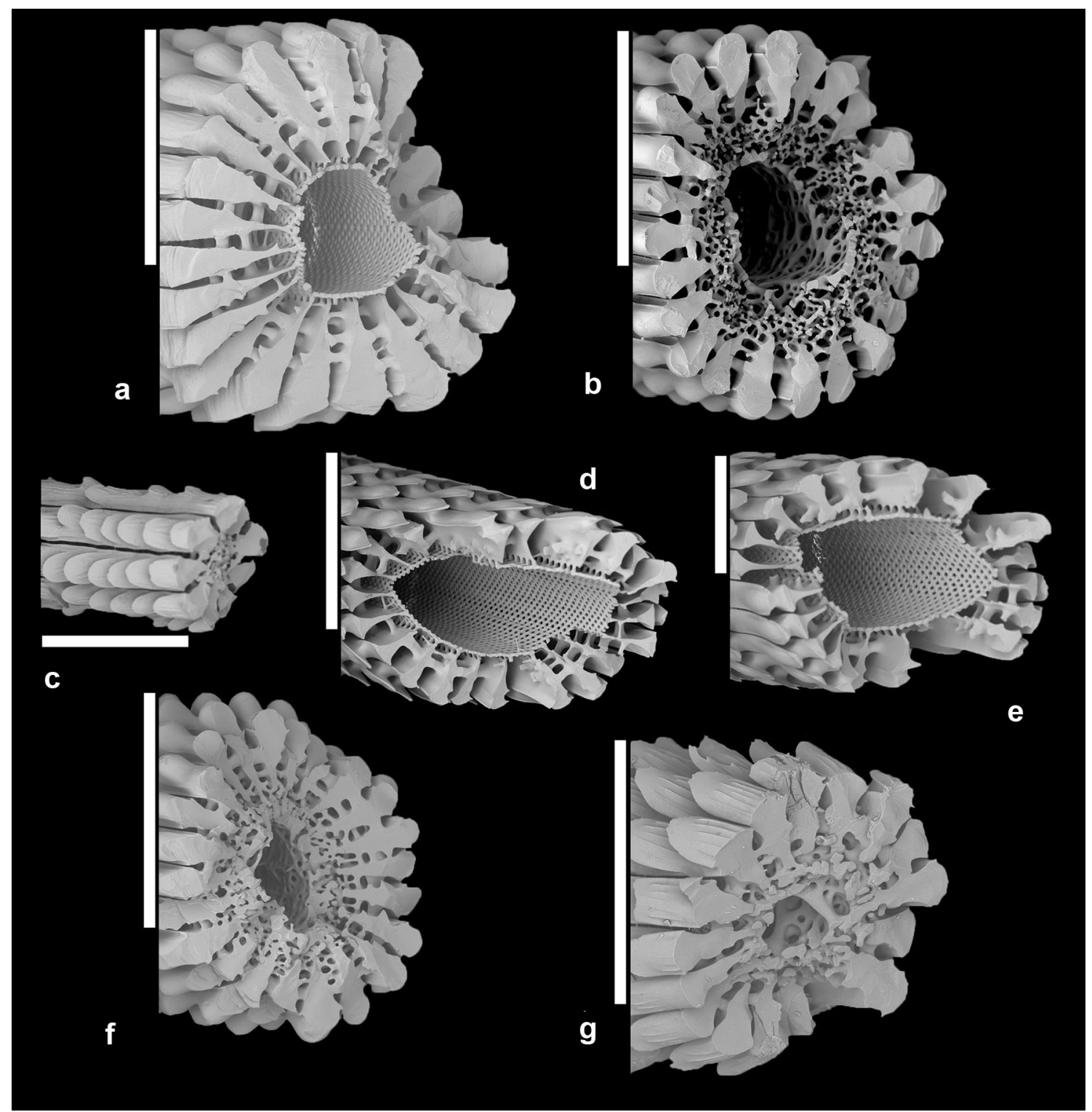

Fig. 5 Diadema antillarum (Philippi), USNM 33219, SE micrographs of broken sections through primary spines. a, b Stub B3, both ends of broken spine. c Stub B1. d Stub B2. e Stub B1, broken distal end

Lytechinus variegatus (Lamarck) (Fig. 10). These spines bear a superficial resemblance to those of $A$. magnifica (Fig. 6). However, the primary spines of $L$. variegatus differ in the medulla having a more open, stereom meshwork (particularly Fig. 10b, e); radial lamellae that vary from the widely separated (Fig. 10a, d) to more robust and braced by numerous concentric trabeculae (Fig. 10c, f); and a cortex which is a thickened continuation of the tra- (different specimen from c). f Stub B2 (different specimen from d). g Stub B3 (different specimen from a, b). Scale bars a, b, d, f represent $1 \mathrm{~mm}, \mathbf{c}, \mathbf{e}, \mathbf{g}$ represent $500 \mu \mathrm{m}$

beculae, similarly braced by 'layers' of concentric trabeculae and numerous round-ended ribs (see also Mortensen 1943 [Camarodonta I], p. 441, fig. 277).

Lytechinus williamsi Chesher (Fig. 11). Distinctly different to the primary spines of L. variegatus and perhaps closer in some ways to those of G. musculata. Centrally, there is a narrow lumen or a central irregular stereom medulla; the inverted triangular plates of the radial 


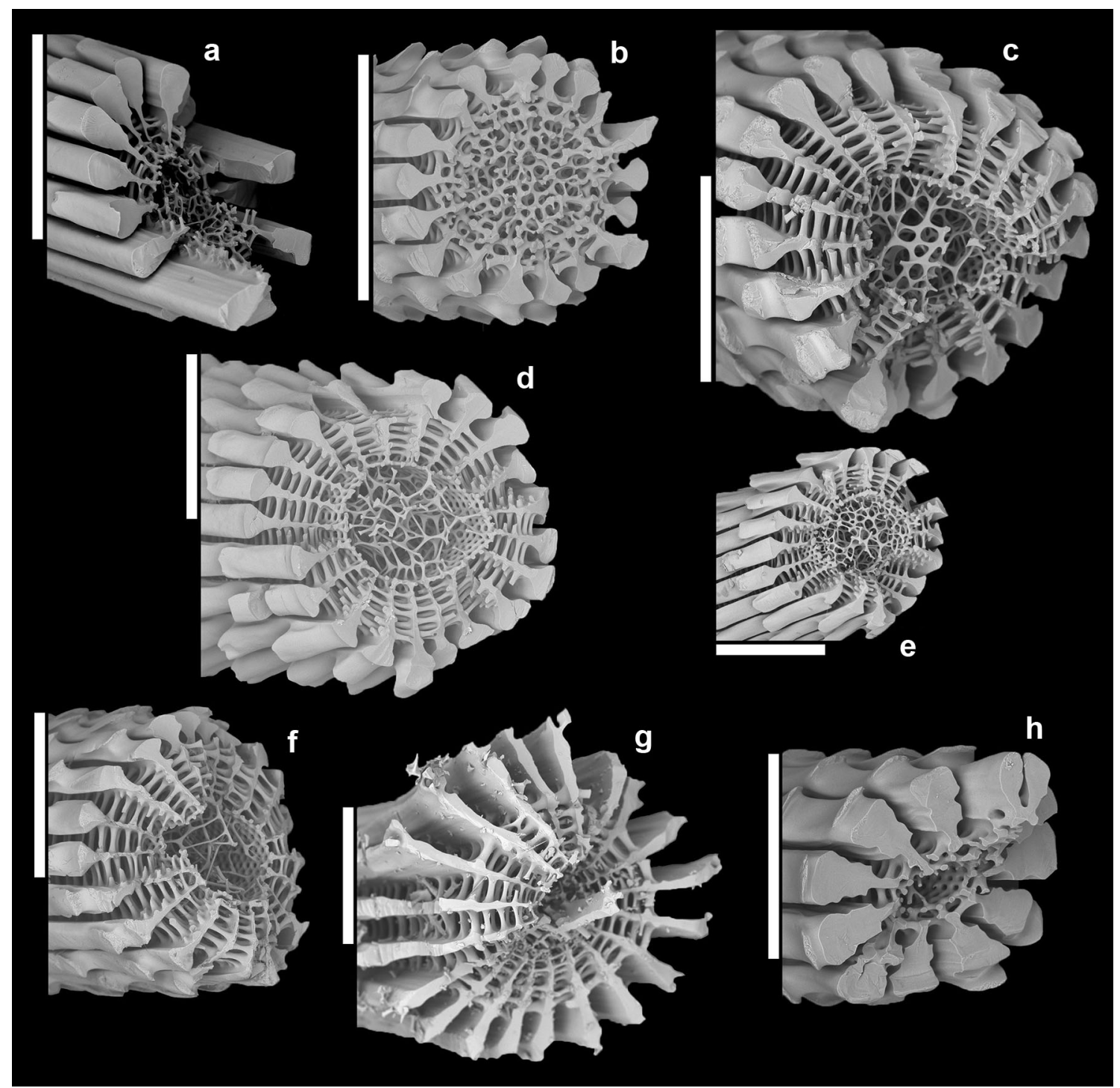

Fig. 6 Astropyga magnifica (A. H. Clark), USNM E15541, SE micrographs of broken sections through primary spines. a, d Stub B4. a lateral view of large spine. d Proximal end of broken spine. b Stub B4 (different specimen from a), tip of slender spine. c Stub B6, broken distal tip of spine. e Stub B5, oblique proximal view of

lamellae/cortex are robust and relatively few (about 12), each rounded and closely spaced at the circumference; and sparse stereom trabeculae separating these plates (see also Chesher 1968, p. 4, fig. 3a, b).

Tripneustes ventricosus (Lamarck) (Fig. 12). The broad lumen that is commonly, but not invariably, present in these spines make them somewhat reminiscent of certain diadematoids (Figs. 5, 7), although one specimen has a fragment. f Stub B5 (different specimen from e, h), distal tip of large spine. g Stub B6 (different specimen from c), proximal end of large spine. h Stub B5 (different specimen from e, f), distal tip of slender spine. All scale bars represent $500 \mu \mathrm{m}$ except $\mathbf{h}$ which represents $300 \mu \mathrm{m}$

dense medulla (Fig. 12e). Where present, the lumen is surrounded by a layer of irregular, medulla-like stereom. Radial lamellae are numerous, gently tapering and terminate in a cortex of rounded ridges. There are moderately thick, concentric layers of stereom separating the lamellae (see also Mortensen 1943 [Camarodonta I], pp. 493-494, fig. 301). 


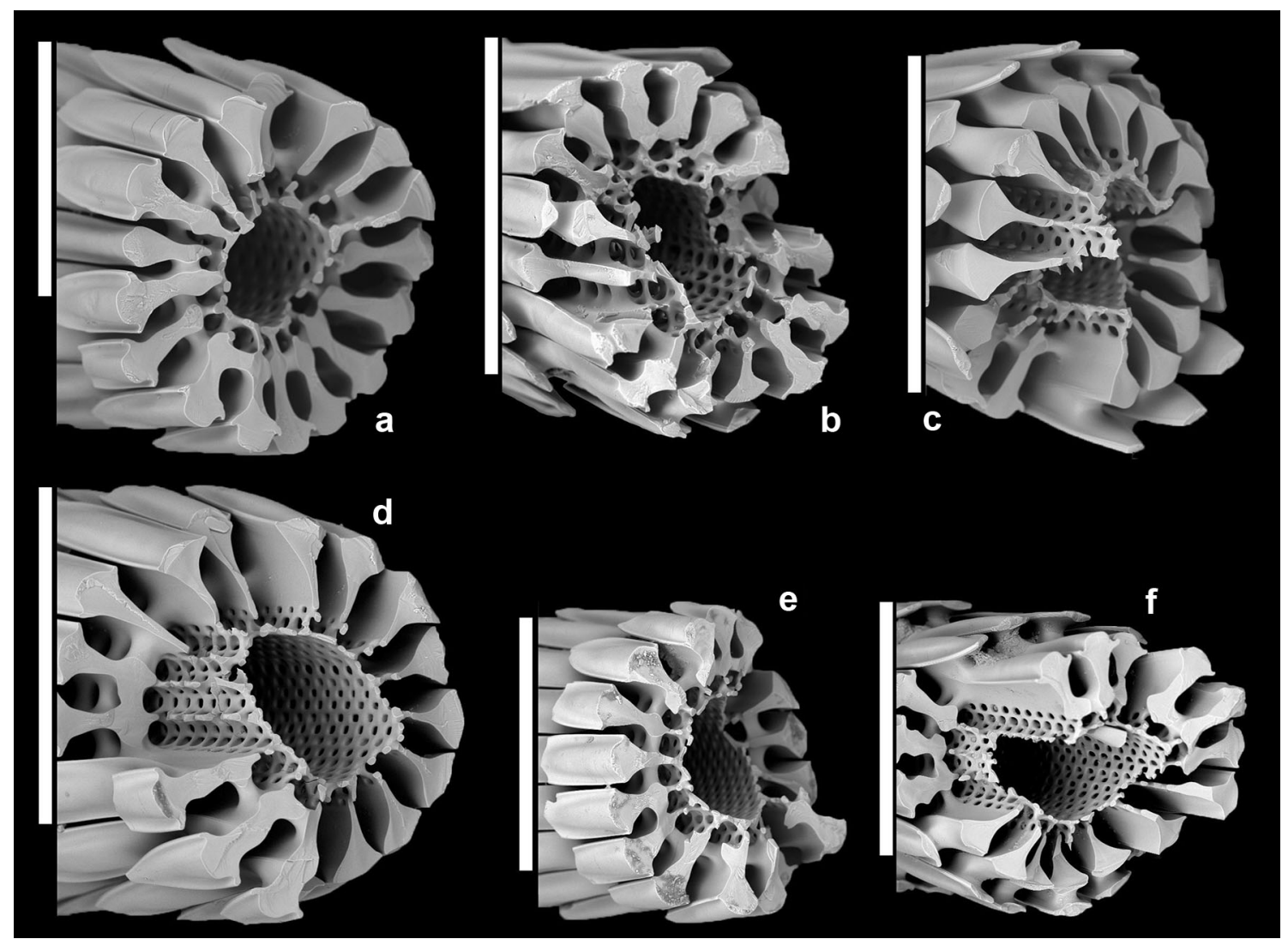

Fig. 7 Centrostephanus longispinus (Philippi), USNM E20008, SE micrographs of broken sections through primary spines. a Stub B7, broken base of a spine. b Stub B7 (different specimen from a, c), broken tip of a spine. c Stub B7 (different specimen from a, b),

Echinometra lucunter (Linnaeus) and Echinometra viridis A. Agassiz (Figs. 13, 14). The sections through the primary spines of both these species of Echinometra are essentially similar. Both have a dense, central medulla, numerous radial lamellae that widen gradually towards the circumference, and which expand at the cortex into closespaced, rounded ridges. Thickened concentric layers of lamellae indicate growth periodically halted and then resumed (see also Mortensen 1943 [Camarodonta II], pp. 363, 370, fig. 175).

\section{Discussion}

Studies of late Cenozoic echinoids in the Antillean region during the recent past have contributed to a fuller determination of the faunal diversity during this interval, broken tip of a spine. d Stub B8, broken base of spine. e Stub B9, broken base of spine. f Stub B9 (different specimen to e), broken tip of spine. All scale bars represent $500 \mu \mathrm{m}$ except a which represents $300 \mu \mathrm{m}$

provided data relevant to determinations of palaeobiological processes (such as biostratinomy) and patterns (including the completeness of the fossil record), and given estimates of depth of deposition of various deposits (see, for example, Donovan 2001, 2003; Donovan and Gordon 1993; Donovan et al. 1994, 2001, 2002, 2016; Gordon 1990; Gordon and Donovan 1992). Indeed, in terms of species per million years, the Plio-Pleistocene echinoid fauna of Jamaica, admittedly with one of the best studied Antillean fossil records from this interval, is now considered to be more diverse than that of the Eocene, which might otherwise be regarded as an 'age of echinoids' (Donovan 2001, 2003). The faunas that have been described from the late Cenozoic differ from those documented hitherto from the region in being based commonly on disarticulated skeletal ossicles, rather than complete tests. Although tests are present and have been included in 


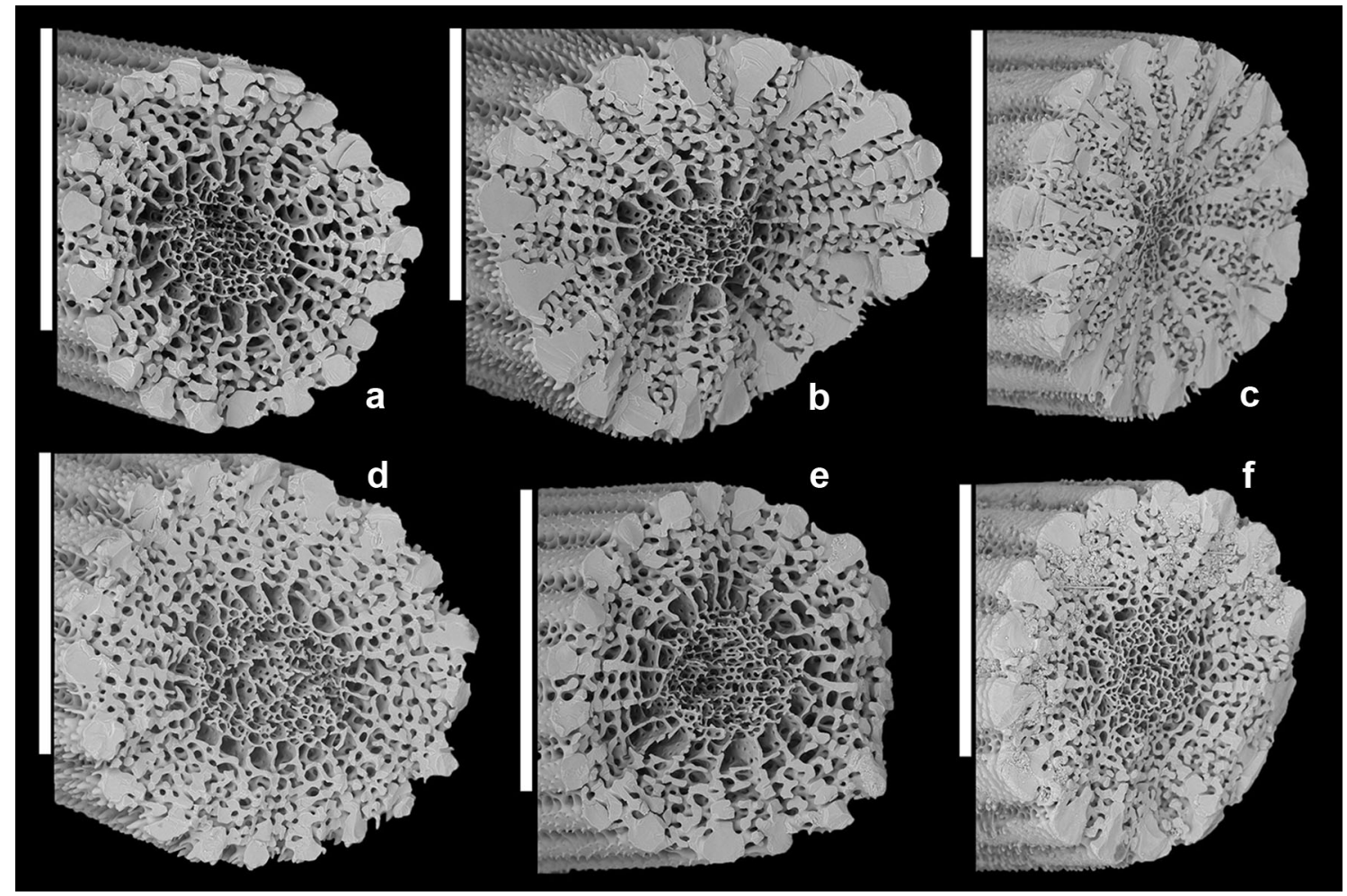

Fig. 8 Arbacia punctulata (Lamarck), USNM E15003, SE micrographs of broken sections through primary spines. a Stub B10, broken end of spine. b Stub B10 (different specimen from a, d), broken end of spine. c Stub B11, broken tip of spine. d Stub B10, broken end of spine (different specimen from a, b). e Stub B12, broken section of spine. f Stub B12 (different specimen from e), broken section of spine. All scale bars represent $500 \mu \mathrm{m}$

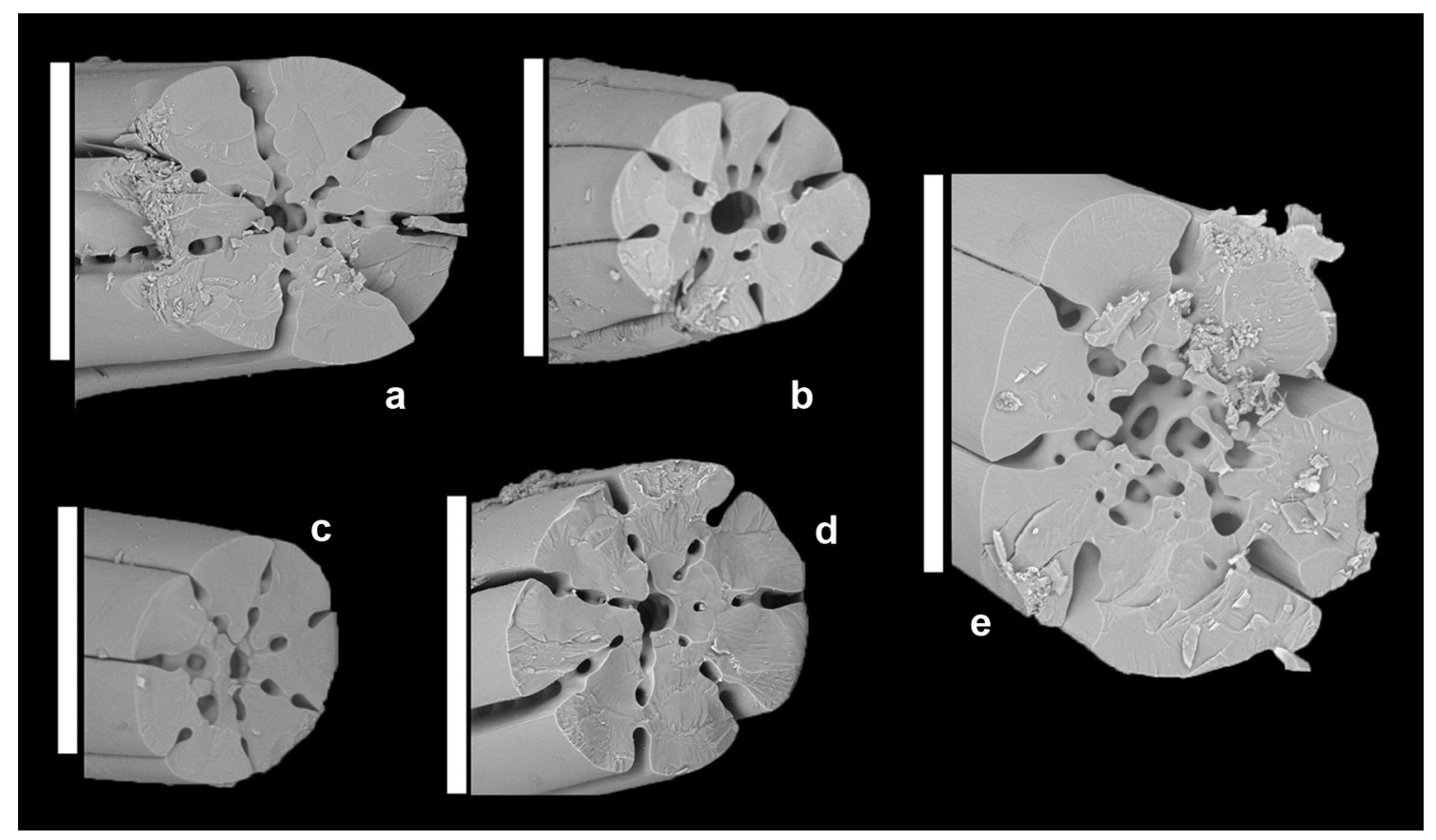

Fig. 9 Genocidaris maculata A. Agassiz, USNM E40228, SE micrographs of broken sections through primary spines. a Stub C1, oblique view of spine. b Stub C2, oblique view of spine fragment. c Stub C3, oblique view of spine fragment. d Stub C2 (different specimen from b), oblique view of broken spine. e Stub C3 (different specimen from c), oblique view of spine fragment. All scale bars represent $200 \mu \mathrm{m}$ 


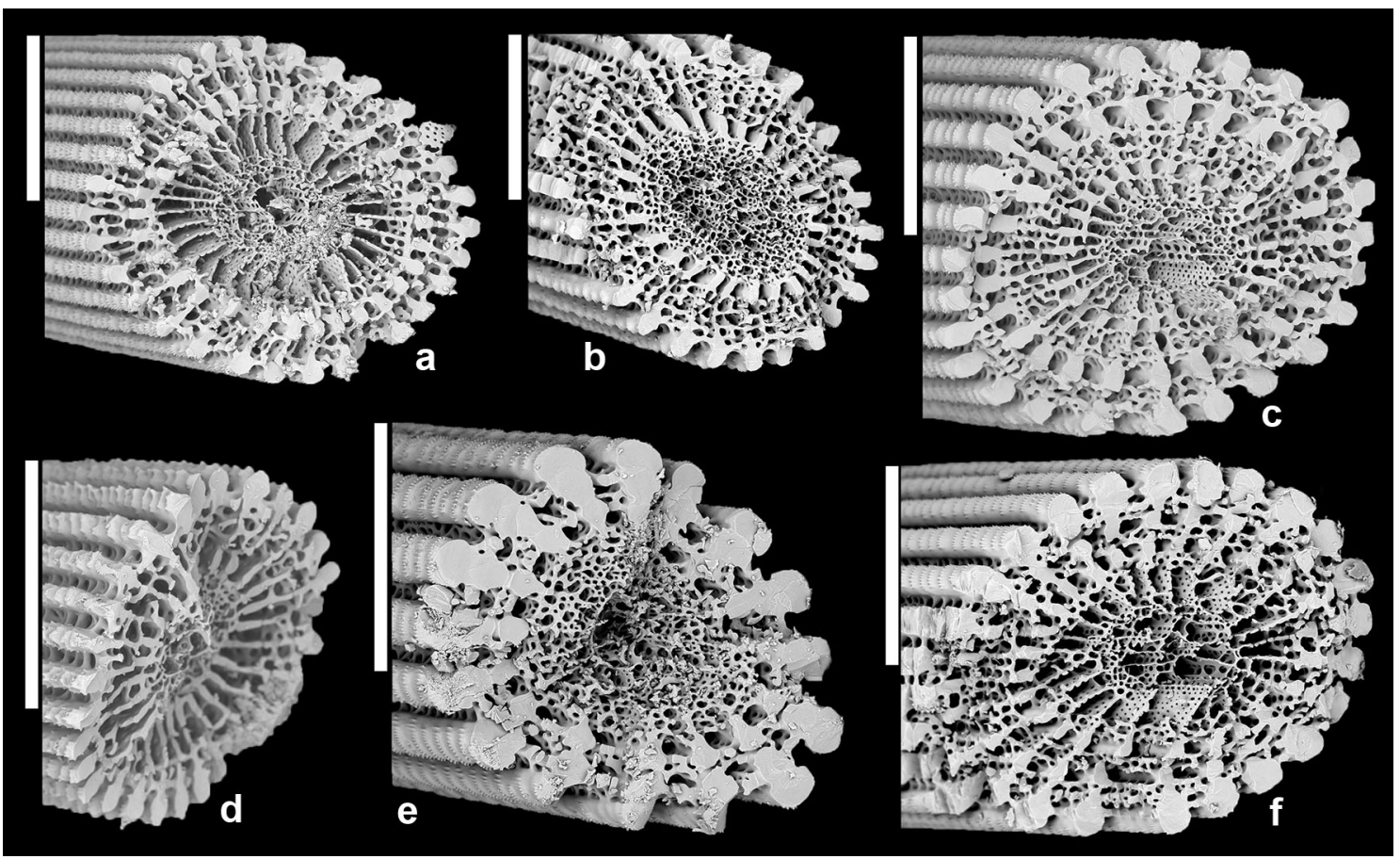

Fig. 10 Lytechinus variegatus (Lamarck), USNM 3088, SE micrographs of broken sections through primary spines. a Stub $\mathrm{C} 4$, broken end of spine. b Stub C5, broken end of spine. c Stub C4 (different specimen from a, d), broken end of base of large spine. d Stub C4 (different specimen from a, c), broken end of small spine (secondary?). e Stub C5 (different specimen from b), broken end of spine. f Stub C6, broken end of long spine. All scale bars represent $500 \mu \mathrm{m}$

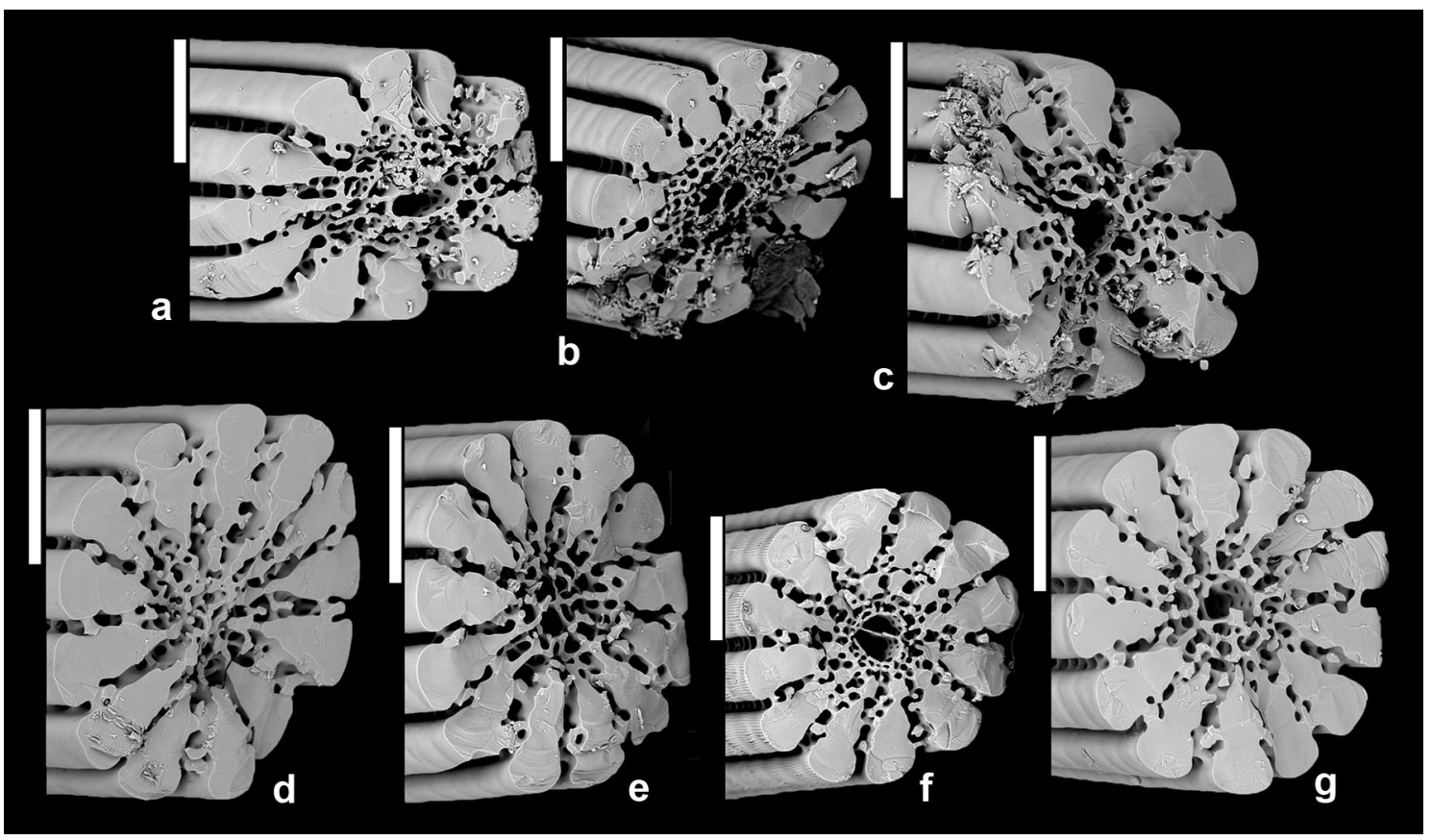

Fig. 11 Lytechinus williamsi Chesher, USNM E14894, SE micrographs of broken sections through primary spines. a Stub C7, distal end of spine. b Stub C7 (different specimen from a, f), broken end of spine. c Stub C8, broken end of long spine. d Stub C9, broken end of spine. e Stub C8 (different specimen from c, g), broken end of spine. f Stub C7 (different specimen from a, b), broken end of spine. g Stub C8 (different specimen from $\mathbf{c}, \mathbf{e}$ ), broken end of spine. All scale bars represent $200 \mu \mathrm{m}$ 


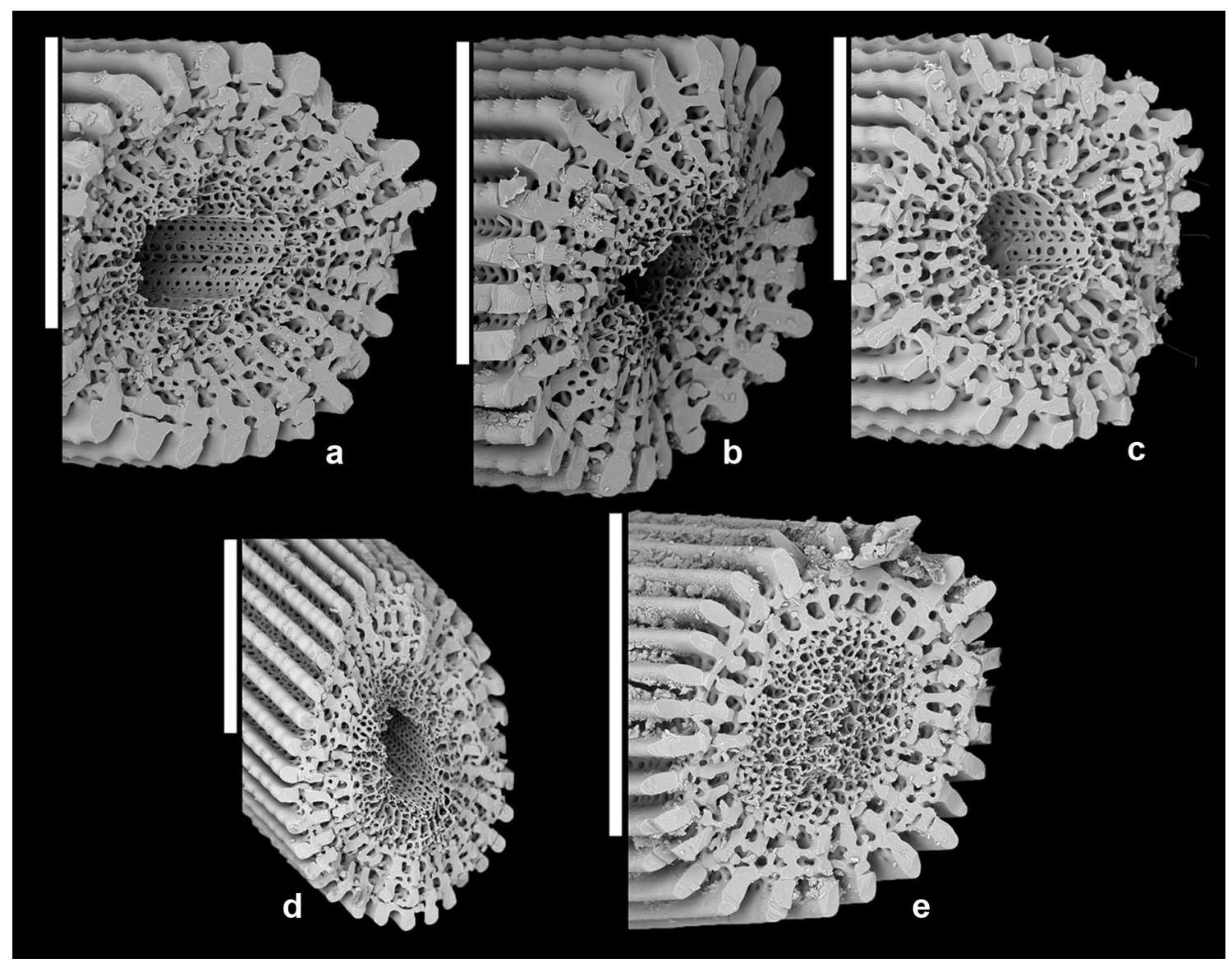

Fig. 12 Tripneustes ventricosus (Lamarck), USNM E27033, SE micrographs of broken sections through primary spines. a Stub C10, broken distal part of large spine. b Stub C10 (different specimen from a, c), broken proximal end of small spine. c Stub C10 (different

analyses, these are far outnumbered by ossicles such as spines, test plates, and lantern elements. To give an extreme example, Gordon's (1990) study of the upper Pleistocene Falmouth Formation raised reef, was based on over 11,000 disarticulated ossicles, but only one test, in a unit from which echinoids had not been documented before! However, for such studies to make a complete scientific contribution, our ability to identify these disarticulated ossicles needs to be refined as fully as possible. specimen from a, b), broken distal end of spine. d Stub C12, oblique view of broken end of small spine. e Stub C12 (different specimen from d), oblique view of broken surface of large spine. All scale bars represent $500 \mu \mathrm{m}$

Hitherto, studies of echinoid spines in the Antillean region have shown that those of cidaroids are identifiable to the level of species (Phelan 1970; Cutress 1980; Donovan 1993; amongst others). For example, spines of all three extant, shallow-water cidaroid species known from the region (Table 1) have been identified in the early Pleistocene of Jamaica (Donovan 2003). Most other regular echinoids have not been analysed in such detail, principally because their fossil spines are less prominent and generally more fragmented than the robust primary spines of 


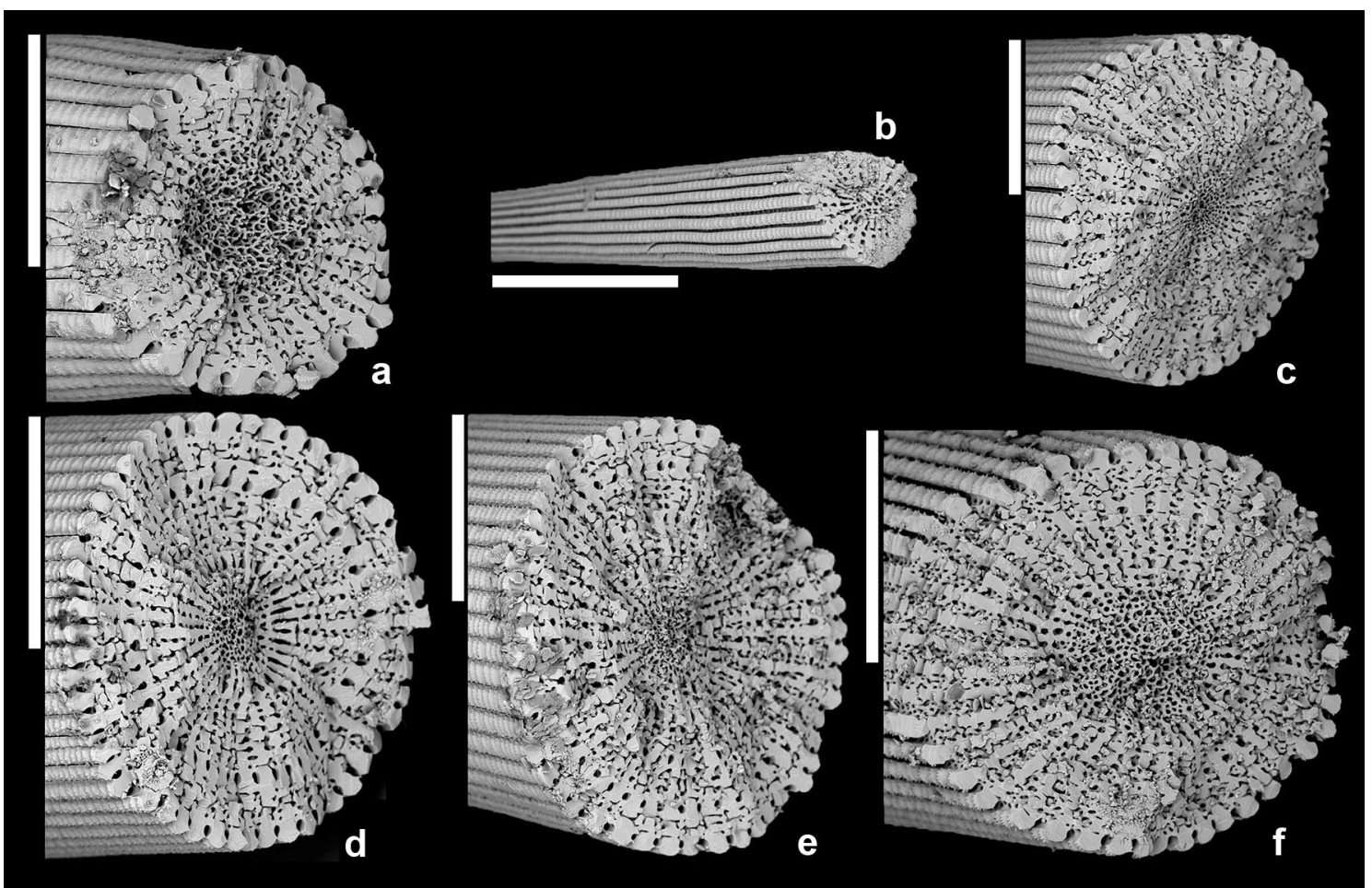

Fig. 13 Echinometra lucunter (Linné), USNM E45614, SE micrographs of broken sections through primary spines. a Stub D1, broken end of spine. b Stub D2, oblique view of small spine. c Stub D1 (different specimen from a, d, e), broken end of spine. d Stub D1

cidaroids, and have been perceived as being of little use in taxonomy. Nevertheless, spines of non-cidaroid regular echinoids have been identified at least to the level of order in some paleontological studies in the Antilles (Gordon 1990; Gordon and Donovan 1992; Donovan and Veltkamp 1992; Donovan and Gordon 1993; Donovan et al. 2001; amongst others). That such studies may be taken further has been demonstrated by a study of the primary spines of the three extant species of shallow water diadematid from the region (Table 1), which have been shown to be morphologically distinct on the basis of both external and internal morphologies (Donovan et al. 2001). An ability to (different specimen from a, c, e), broken end of spine. e Stub D1 (different specimen from a, c, d), broken end of spine. f Stub D2 (different specimen from b), broken end of spine. All scale bars represent $500 \mu \mathrm{m}$

identify such spines of regular echinoids to the level of species has considerable potential for providing more accurate data for studies of ancient biodiversity, evolution, and palaeoecology, including depth of deposition, of the late Cenozoic of the region.

The present compilation (Figs. 1, 2, 3, 4, 5, 6, 7, 8, 9, 10, $11,12,13,14)$ is a widely applicable research tool for both palaeontologists and sedimentologists. The group of taxa is chosen, because it is anticipated that many, although not all, late Cenozoic deposits in the region would have been laid down in shallower rather than deeper water. Furthermore, deep water deposits may commonly include echinoid 


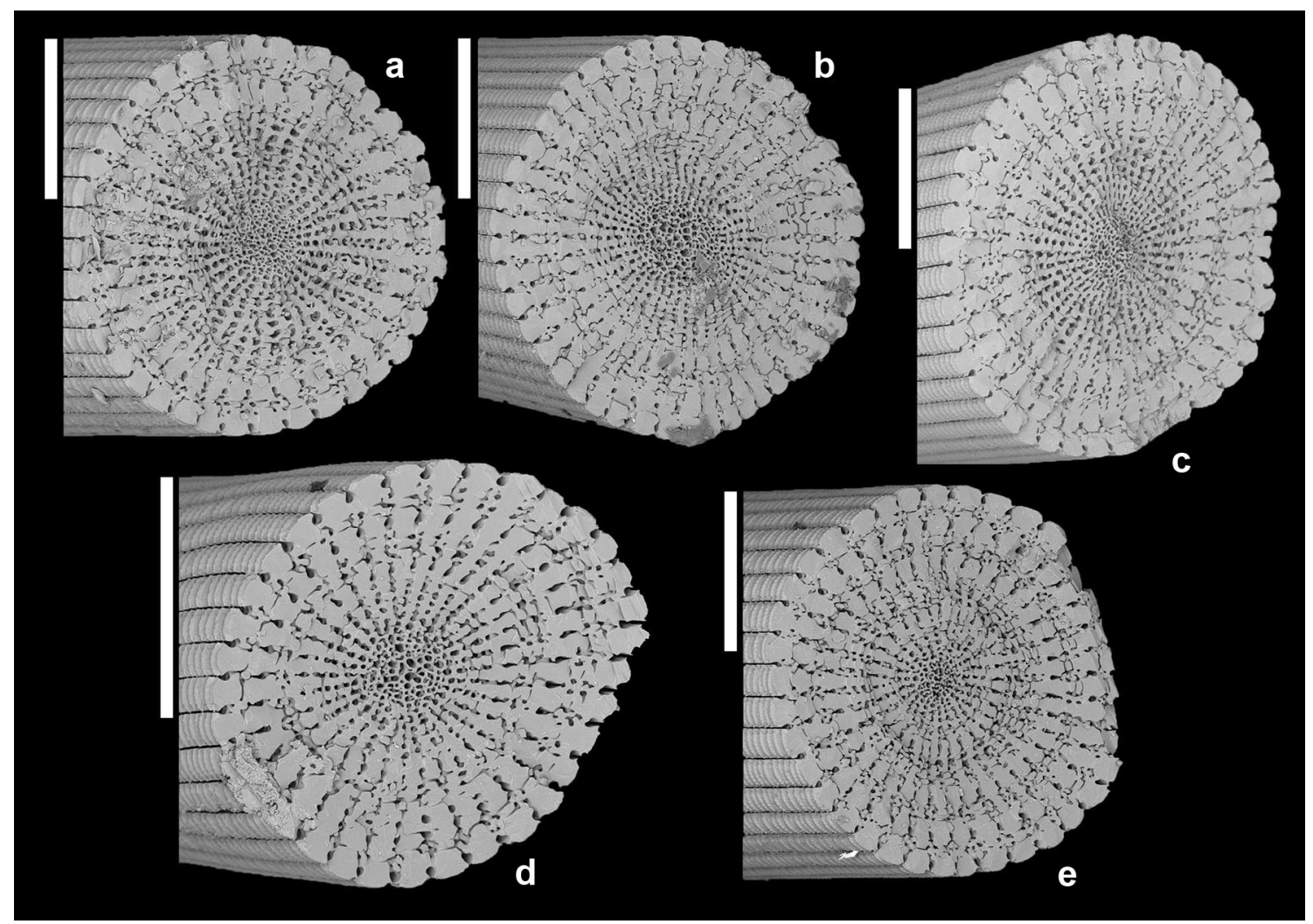

Fig. 14 Echinometra viridis A. Agassiz, USNM E14570, SE micrographs of broken sections through primary spines. a Stub D3, broken end of spine. b Stub D3 (different specimen from a, d), broken end of spine. c Stub D4, broken end of spine. d Stub D3 (different specimen from a, b), broken end of spine. e Stub D4 (different specimen from c), broken end of spine. All scale bars represent $500 \mu \mathrm{m}$ debris derived from shallower water (Donovan et al. 2005) and many of these taxa range into deeper water at the present day (Table 1), making accurate recognition of their spines of broader utility. Regular echinoids are not commonly preserved as complete specimens in the fossil record (Kier 1977; Smith 1984), but rather occur as disarticulated fragments. Irregular echinoids have not been included in the present study because of the even smaller size of their spines and their (relatively) common preservation as tests.

Acknowledgements I gratefully acknowledge a Smithsonian Institution Short-Term Visitor Grant in August 2012 in support of this research. My host, Dr. David L. Pawson (Department of Invertebrate Zoology, USNM), is thanked for his kind encouragement and support. Mr. Scott Whittaker ably instructed me in the operation, mysteries, and foibles of the Hitachi TM3000 SEM, and provided all necessary support to ensure a successful outcome. Incisive reviews by Dr. Andreas Kroh (Natural History Museum Vienna) and a second, anonymous referee are gratefully acknowledged.

\section{Appendix}

Registration numbers, locality data, and other relevant information are included for all specimens considered herein. Taxa are presented in the same order as in Figs. 1, $2,3,4,5,6,7,8,9,10,11,12,13$, and 14. All specimens were stored dry; single tests unless stated otherwise.

Eucidaris tribuloides (Lamarck) (Fig. 1). USNM 10734. North Atlantic Ocean, Gulf of Mexico; United States; between Mississippi Delta and Cedar Keys, Florida; $27^{\circ}$ $47^{\prime} 30^{\prime \prime} \mathrm{N} 84^{\circ} 37^{\prime} 00^{\prime \prime} \mathrm{W} ; 24$ fathoms; Albatross R/V; 15 March 1885. Determined by R. Rathbun. There are two trays bearing this number, both boxes with about 30 specimens. Spines came loose from the floor of one box and were mounted on three stubs, informally numbered [A1, A2, A3].

Stylocidaris affinis (Philippi) (Fig. 2). USNM 27840. North Atlantic Ocean, Gulf of Mexico; United States; Florida, Florida Keys, off Key West; $24^{\circ} 25^{\prime} 45^{\prime \prime} \mathrm{N} 81^{\circ} 46^{\prime}$ $00^{\prime \prime} \mathrm{W} ; 45$ fathoms; Albatross R/V; 15 January 1885. Determined by R.T. Jackson. Stubs [A4, A5, A6]. 
Tretocidaris bartletti (A. Agassiz) (Fig. 3). USNM E11897 (acc. \#296540). North Atlantic Ocean, Caribbean Sea; off of Dominican Republic; $18^{\circ} 21^{\prime} 24^{\prime \prime} \mathrm{N} 69^{\circ} 8^{\prime} 42^{\prime \prime}$ W (station \#1387); 165 m; Pillsbry R/V; 9 July 1971. Determined by F.J. Fell. Stubs [A7, A8, A9].

Phormosoma placenta sigsbei A. Agassiz (Fig. 4). USNM E12320. North Atlantic Ocean, Caribbean Sea; off Saint Lucia; $14^{\circ} 5.2^{\prime} \mathrm{N} 60^{\circ} 50.3^{\prime} \mathrm{W}$; 265-567 m; Pillsbry R/V; 7 July 1969. Determined by K. Serafy. Stubs [A10, A11, A12].

Diadema antillarum (Philippi) (Fig. 5). USNM 33219 (acc. \#053569). North Atlantic Ocean, Gulf of Mexico; United States; Florida, Florida Keys, Loggerhead Key; coll. T.W. Vaughan; 3 May 1908. Determined by A.H. Clark. Four specimens. Stubs [B1, B2, B3].

Astropyga magnifica A.H. Clark (Fig. 6). USNM E15541. North Atlantic Ocean; United States; Florida, Jacksonville; $30^{\circ} 31^{\prime} 24^{\prime \prime} \mathrm{N} 80^{\circ} 5^{\prime} 6^{\prime \prime} \mathrm{W} ; 252 \mathrm{~m} ; 19$ August 1974. Determined by M.E. Downey. Stubs [B4, B5, B6].

Centrostephanus longispinus Philippi (Fig. 7). USNM 20008. North Atlantic Ocean; Gulf of Guinea; $4^{\circ} 32^{\prime} \mathrm{N}$ $5^{\circ} 7^{\prime} \mathrm{E}$ to $4^{\circ} 31^{\prime} \mathrm{N} 5^{\circ} 13^{\prime} \mathrm{E}^{\prime}$ (station \#245); 64-119 m; Pillsbry R/V; 13 May 1965. Determined by F.J. Fell. Stubs [B7, B8, B9].

Arbacia punctulata (Lamarck) (Fig. 8). USNM E15003. North Atlantic Ocean; Gulf of Mexico; United States; Florida, 36 miles due $\mathrm{W}$ of Egmont Key; $27^{\circ} 37^{\prime} \mathrm{N}$ $83^{\circ} 28^{\prime} \mathrm{W} ; 120 \mathrm{ft} ; 11$ September 1967. Determined by K. Serafy. Stubs [B10, B11, B12].

Goniocidaris maculata A. Agassiz (Fig. 9). USNM E40228. North Atlantic Ocean; Gulf of Mexico; W of Fort Myers, Florida; collected CSA for MMS; 1 February 1982. Determined by unknown. Ten specimens; one bleached, loose spines bleached. Stubs [C1, C2, C3].

Lytechinus variegatus (Lamarck) (Fig. 10). North Atlantic Ocean; United States; Florida. Determined by unknown. Stubs [C4, C5, C6].

Lytechinus williamsi Chesher (Fig. 11). USNM E14894. North Atlantic Ocean; Cape Eleuthera, Bahamas; Acropora cervicornis reef, 1-8 ft; 8 July 1975 . Collected and determined by R.H. Chesher. Two tests. Stubs [C7, C8, C9].

Tripneustes ventricosus (Lamarck) (Fig. 12). USNM E27033. North Atlantic Ocean; Caribbean Sea; W of Pigeon Point, Tobago; depth unknown; collected by W.L. Schmitt. Determined by C. Gust. Stubs [C10, C11, C12].

Echinometra lucunter (Linné) (Fig. 13). USNM E4514. North Atlantic Ocean; Caribbean Sea; off S coast of Barbados, Warsaw; collected by University of Iowa BarbadosAntigua Expedition 1918. Determined by unknown. Stubs [D1, D2].

Echinometra viridis A. Agassiz (Fig. 14). USNM E14570. North Atlantic Ocean; Caribbean Sea; Panama; $9^{\circ} 37^{\prime} 42^{\prime \prime} \mathrm{N} 79^{\circ} 34^{\prime} 12^{\prime \prime} \mathrm{W}$; collected by unknown; 5-20 ft;
1967. Determined by R. Chesher. Four specimens. Stubs [D3, D4].

\section{References}

Agassiz, A. (1863). List of the echinoderms sent to different institutions in exchange for other specimens, with annotations. Bulletin of the Museum of Comparative Zoology (Harvard), 1, 17-28.

Agassiz, A. (1869). Preliminary report of the echini and star-fishes dredged between Cuba and the Florida reef, by L.F. de Pourtalés, Assist. U.S. Coast Survey. Bulletin of the Museum of Comparative Zoology (Harvard), 1, 253-308.

Agassiz, A. (1880). Preliminary report on the echini. Reports on the results of dredging, under the supervision of Alexander Agassiz, in the Caribbean Sea in 1878-1879, and along the Atlantic Coast of the United States during the summer of 1880 , by the U.S. Coast Survey Steamer "Blake". IX. Bulletin of the Museum of Comparative Zoology (Harvard), 8(2), 69-84.

Ausich, W. I. (1997). Regional encrinites: A vanished lithofacies. In C. E. Brett \& G. C. Baird (Eds.), Paleontological events: Stratigraphic, ecological, and evolutionary implications (pp. 509-519). New York: Columbia University Press.

Benton, M. J., \& Simms, M. J. (1995). Testing the marine and continental fossil records. Geology, 23, 601-604.

Benton, M. J., \& Simms, M. J. (1996). Testing the marine and continental fossil records: Reply. Geology, 24, 381-382.

Chesher, R. H. (1968). Lytechinus williamsi, a new sea urchin from Panama. Breviora, 305, 1-13.

Clark, A. H. (1934). A new sea-urchin from Florida. Journal of the Washington Academy of Sciences, 24, 52-53.

Clark, H. L. (1907). The Cidaridae. Bulletin of the Museum of Comparative Zoology, 51(7), 163-230.

Clark, H. L. (1912). Hawaiian and other Pacific echini. The Pedinidae, Phymosomatidae, Stomopneustidae, Echinidae, Temnopleuridae, Strongylocentrotidae, and Echinometridae. Memoirs of the Museum of Comparative Zoology (Harvard), 34(4), 1-180.

Cutress, B. M. (1980). Cretaceous and Tertiary Cidaroida (Echinodermata: Echinoidea) of the Caribbean area. Bulletins of American Paleontology, 77(309), 1-221.

De Lamarck, J. B. P. A. (1816). Histoire naturelle des animaux sans vertèbres, présentant les caractères, généralaux et particuliers de ces animaux, leurs distribution, leurs classes, leurs familles, leurs genres et la citation synonymique des principales espèces qui s'y rapportent, 1 st edn, vol. 3. Paris (not seen).

Donovan, S. K. (1993). Jamaican Cenozoic Echinoidea. In R. M. Wright \& E. Robinson (Eds.), Biostratigraphy of Jamaica. (pp. 371-412). Geological Society of America Memoir. Vol. 182.

Donovan, S. K. (1996). Testing the marine and continental fossil records: Comment. Geology, 24, 381.

Donovan, S. K. (2001). Evolution of Caribbean echinoderms during the Cenozoic: Moving towards a complete picture using all of the fossils. Palaeogeography, Palaeoclimatology, Palaeoecology, 166, 177-192.

Donovan, S. K. (2003). Completeness of a fossil record: The Pleistocene echinoids of the Antilles. Lethaia, 36, 1-7.

Donovan, S. K., Dixon, H. L., Pickerill, R. K., \& Doyle, E. N. (1994). Pleistocene echinoid (Echinodermata) fauna from southeast Jamaica. Journal of Paleontology, 68, 351-358. 
Donovan, S. K., \& Gordon, C. M. (1993). Echinoid taphonomy and the fossil record: Supporting evidence from the Plio-Pleistocene of the Caribbean. Palaios, 8, 304-306.

Donovan, S. K., Harper, D. A. T., Blackman, I. M., \& Simpson, G. A. (2002). Pleistocene echinoids from fore reef palaeoenvironments in Barbados and eastern Jamaica: A comparison. In T. A. Jackson (Ed.), Caribbean geology: Into the 3rd millennium. Transactions of the 15th Caribbean Geological Conference, 29th June-2nd July, 1998, Kingston, Jamaica (pp. 167-171). Mona: The Press, University of the West Indies.

Donovan, S. K., Jones, B., \& Harper, D. A. T. (2016). Neogene echinoids from the Cayman Islands, West Indies: Regional implications. Geological Journal, 51, 864-879.

Donovan, S. K., Lewis, D. N., Vincent, H., \& Blackman, I. M. (2001). Pleistocene echinoids from Tobago, West Indies. Caribbean Journal of Earth Science, 35, 1-12.

Donovan, S. K., \& Paul, C. R. C. (Eds.). (1998). The adequacy of the fossil record. Chichester: Wiley.

Donovan, S. K., Portell, R. W., \& Veltkamp, C. J. (2005). Lower Miocene echinoderms of Jamaica, West Indies. Scripta Geologica, 129, 91-135.

Donovan, S. K., \& Veltkamp, C. J. (1992). A diadematoid echinoid from the Lower Paleocene of Jamaica. Caribbean Journal of Science, 28, 222-224.

Durham, J. W., \& Wagner, C. D. (1966). Glossary of morphological terms applied to echinoids. In R. C. Moore (Ed.), Treatise on invertebrate paleontology. Part $U$, Echinodermata (3(1) ed., pp. U251-U256). New York: Geological Society of America and University of Kansas.

Gordon, C. M. (1990). Taxonomy and palaeoecology of the echinoids of the Late Pleistocene Falmouth Formation of Jamaica. Unpublished M.Phil. thesis. Mona: University of the West Indies.

Gordon, C. M., \& Donovan, S. K. (1992). Disarticulated echinoid ossicles in paleoecology and taphonomy: The last interglacial Falmouth Formation of Jamaica. Palaios, 7, 157-166.

Hendler, G., Miller, J. E., Pawson, D. L., \& Kier, P. M. (1995). Sea stars, sea urchins, and allies: Echinoderms of Florida and the Caribbean. Washington, D.C.: Smithsonian Institution Press.

Kier, P. M. (1977). The poor fossil record of the regular echinoid. Paleobiology, 3, 168-174.
Linné, C. (1758). Systema Naturae per Regna tria naturae, secundum classes, ordines, genera, species, cum characteribus differentis, synonymis, locis. Holmiae (not seen).

Melville, R. V., \& Durham, J. W. (1966). Skeletal morphology. In R. C. Moore (Ed.), Treatise on invertebrate paleontology. Part $U$, Echinodermata (Vol. 3(1), pp. U220-U251). New York: Geological Society of America and University of Kansas.

Mortensen, T. (1903). The Danish ingolf-expedition 1895-1896, Vol. 4, no. 1. Echinoidea, pt. 1. Copenhagen (translated into English by Torben Lundbeck).

Mortensen, T. (1928-1951). A monograph of the Echinoidea. In five volumes. Copenhagen: Reitzel.

Pawson, D. L., Vance, D. J., Messing, C. G., Solís-Marin, F. A., \& Mah, C. L. (2009). Echinodermata of the Gulf of Mexico. In D. L. Felder \& D. K. Camp (Eds.), Gulf of Mexico-Origin, waters, and biota. Volume 1 - Biodiversity (pp. 1177-1204). College Station: Texas A\&M University Press.

Phelan, T. (1970). A field guide to the cidaroid echinoids of the northwestern Atlantic Ocean, Gulf of Mexico, and the Caribbean Sea. Smithsonian Contributions to Zoology, 40, 1-67.

Philippi, R. A. (1845). Beschreibung einiger neuer Echinodermen (Spatangus excavata, Sp. cavernosus, Sp. Australia, Sp. placenta, Sp. canaliferus) nebst kritischen Bemerkungen über einige weniger bekannte Arten. Archiv für Naturgeschite Jahrgang, 11, 344-359.

Serafy, D. K. (1979). Echinoids (Echinodermata: Echinoidea). Memoirs of the Hourglass Cruises, 5(3), 1-120.

Smith, A. B. (1984). Echinoid palaeobiology. London: George Allen and Unwin.

Smith, A. B., \& Kroh, A. (Eds.) (2011). The echinoid directory. World Wide Web electronic publication. http://www.nhm. ac.uk/research-curation/projects/echinoid-directory. Accessed Mar 2018.

Troschel, F. H. (1869). Über einige neue Seeigel. In: Anonymous: Sitzungsberichte. Physikalische Section. Sitzung vom 21. Juni. Verhandlungen des naturhistorischen Vereines des preussischen Rheinlande und Westphalens, 26, p. 96.

Wyville Thomson, J. (1872). On the Echinoidea of the "Porcupine" deep-sea dredging expeditions. Proceedings of the Royal Society of London, 20, 491-497. 